\title{
CD151 Gene
}

National Cancer Institute

\section{Source}

National Cancer Institute. CD151 Gene. NCI Thesaurus. Code C102464.

This gene plays a role in cell-matrix adhesion. 